\title{
The Progressive Reduction in the Ovarian Reserve in Young Women After Anticancer Treatment
}

Authors

Affiliations

\author{
M. Krawczuk-Rybak ${ }^{1}$, E. Leszczynska ${ }^{1}$, M. Poznanska' ${ }^{1}$, B. Zelazowska-Rutkowska² , J. Wysocka ${ }^{2}$
}

${ }^{1}$ Department of Paediatric Oncology and Hematology, Medical University of Bialystok, Bialystok, Poland ${ }^{2}$ Department of Paediatric Laboratory Diagnostics, Medical University of Bialystok, Bialystok, Poland
Key words

cancer survivors

- gonadotoxicity

fertility

- anti-Müllerian hormone

- premature menopause received 11.02.2013

accepted 17.06.2013

Bibliography DOI http://dx.doi.org/ 10.1055/s-0033-1349854 Published online: August 15, 2013 Horm Metab Res 2013; 45: 813-819

(c) Georg Thieme Verlag KG Stuttgart · New York ISSN 0018-5043

Correspondence M. Krawczuk-Rybak Department of Paediatric Oncology and Hematology Medical University 15-274 Bialystok Ul. Waszyngtona 17 Poland

Tel.: +48/85/7450 846 Fax: $+48 / 85 / 7450846$ rybak@umb.edu.pl

\section{Abstract \\ $\nabla$}

Anticancer treatment can disturb gonadal function and deplete the primordial follicle pool, leading to premature menopause. We made a prospective analysis of serum hormone levels in young female cancer survivors who had been treated during childhood and adolescence. Serum anti-Müllerian hormone (AMH) as a marker of ovarian reserve, $\mathrm{FSH}, \mathrm{LH}$, and estradiol were measured in 33 women treated previously (6-11 years earlier) for Hodgkin Lymphoma, solid tumours, and after bone marrow transplantation, and in 34 healthy controls. The group of survivors was divided according to the risk of gonadotoxicity into the low risk and median risk group (LR+MR), and into the high risk (HR) group. The measurements were

\section{Introduction \\ $\nabla$}

Composed anticancer treatment, successfully used in children in the last 40 years, has caused a prolonged survival, but it has also provoked different systemic late effects in cancer survivors. The gonads are susceptible to damage, particularly by the alkylating agents (cyclophosphamide, melphalan, busulphan, procarbazine) and/ or radiation to the areas of the ovaries or testicles [1-3]. This kind of treatment damages rapidly dividing cells, leading to spermatogenesis deterioration in men and depletion of oocytes in women. Development of infertility or impaired fertility differs between sexes. In men, spermatogenesis can be disturbed during and after cytotoxic anticancer treatment due to depletion of the proliferating germ-cell pool, which results in infertility or subfertility. In women, gonadotoxic therapy initiates deterioration of ovarian function, damages the primordial follicles in the ovaries, thus leading to premature menopause $[4,5]$. repeated after 5 years. In the HR group, AMH levels were significantly lower than in controls $(p=0.001)$ and in the LR+MR group $(p=0.006)$ at the time of the first examination fell progressively after 5 years $(p=0.03)$, whereas elevated FSH values $(p=0.053)$ increased $(p=0.001)$. Unchanged $\mathrm{LH}$ values in the first measurement rose in the second one $(p=0.001)$. In the $L R+M R$ group, the levels of AMH and FSH were normal (compared to the control) at baseline, but after 5 years serum AMH decreased $(p=0.027)$ and FSH increased $(p=0.008)$. Our findings indicate that anticancer treatment during childhood and adolescence is associated with a serious, progressive risk of ovarian failure. It is necessary to inform female cancer survivors, especially the high risk patients, about the risk of premature menopause.

In recent years, serum inhibin $B$ and anti-Müllerian hormone $(\mathrm{AMH})$ measurements have been used as sensitive direct markers of the ovarian reserve, even for predicting age at menopause. Inhibin B is a product of granulosa cells in antral follicles; it suppresses FSH (follicle-stimulating hormone) production in the hypothalamic-pituitary-ovarian axis. During the menstrual cycle, the level of inhibin B changes, being the highest in the early follicular phase and at the time of ovulation. AMH is produced by granulosa cells of the primary, preantral and little antral follicles. The serum level of AMH during the menstrual cycle is relatively stable and does not seem to remain under hormonal influence. Serum AMH and inhibin $B$ levels are related to age and number of antral follicles. The measurement of inhibin B and AMH can be very helpful for predicting ovarian failure and premature menopause in women treated for different neoplasms [6-8]. We previously found lower AMH levels only in girls receiving infradiaphragmatic radiotherapy, whereas in 


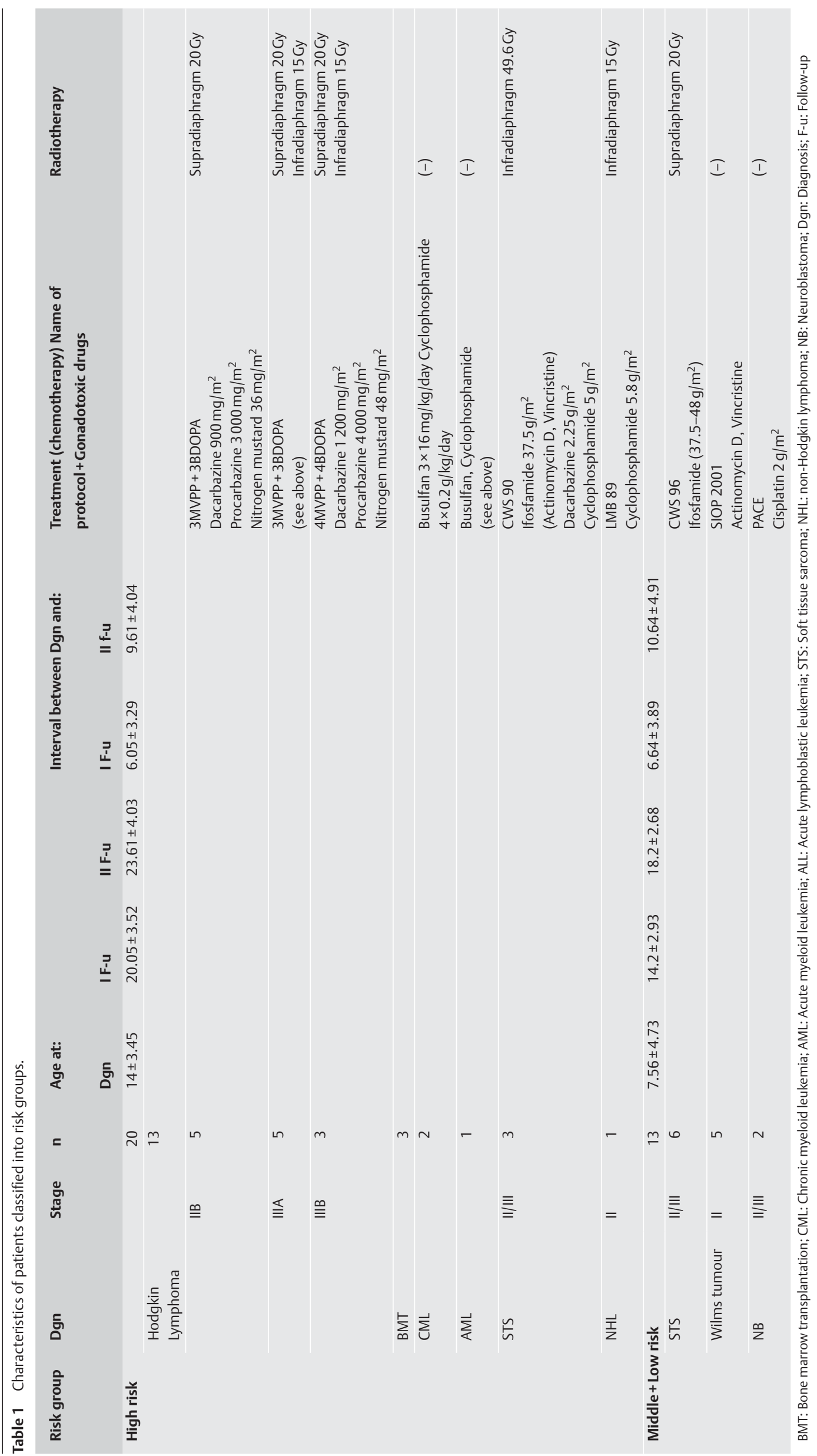


all the study groups of survivors the levels of AMH, LH (luteinizing hormone), and FSH did not differ as compared to healthy peers [9]. In the present prospective study, we assess the ovarian reserve in part of the same group of cancer survivors after a 5 -year period.

\section{Patients and Methods \\ $\nabla$}

Thirty-three young women treated previously (1995-2003) in the Department of Paediatric Oncology and Haematology, Medical University of Bialystok, Poland, were recruited to the study from the group of young cancer survivors. They gave consent to participate in the longitudinal study on the gonadal function and were classified according to the possible degree of gonadotoxicity proposed by Wallace et al. The risk of disturbed fertility or infertility depends on diagnosis, stage, kind of treatment (alkylating agents, radiotherapy to the pelvis/ovaries). The probability of infertility in the low risk group is less than $20 \%$, in the medium risk group between $20-80 \%$, whereas in the high risk group $>80 \%[5]$.

Details concerning diagnosis, age at the time of therapy, type of therapy, the interval between the end of therapy and measurements of hormone levels are presented in 0 Table 1, taking into consideration the risk groups proposed by Wallace et al. [5]. The patients after megachemotherapy, diagnosed with Hodgkin lymphoma and soft tissue sarcoma (located in the pelvis or after multiple recurrences) were included in the high risk group, whereas those diagnosed with Wilms tumour, neuroblastoma (stage II), germ tumours, and soft tissue sarcoma in the low or median risk group.

The first hormonal analysis was made between 2006-2007, whereas the second one between 2010 and 2012, with a 4-6 years interval between the 2 measurements. All the patients were treated 6-11 years earlier, according to the protocols of the Polish Paediatric Leukaemia/Lymphoma and Solid Tumours Study Group (based on international/European protocols). Patients diagnosed with Hodgkin lymphoma (HL) were treated with MVPP and B-DOPA protocols \pm radiotherapy. The MVPP protocol was composed of nitrosourea (nitrogranulogen) $2 \times 6 \mathrm{mg} /$ $\mathrm{m}^{2}$, vinblastine $2 \times 6 \mathrm{mg} / \mathrm{m}^{2}$, procarbazine $100 \mathrm{mg} / \mathrm{m}^{2}$ for 10 days, and prednisone $40 \mathrm{mg} / \mathrm{m}^{2}$ for 10 days. The B-DOPA protocol included: bleomycin $2 \times 4 \mathrm{mg} / \mathrm{m}^{2}$, dacarbazine $5 \times 150 \mathrm{mg} / \mathrm{m}^{2}$, vincristine $2 \times 1.5 \mathrm{mg} / \mathrm{m}^{2}$, adriamycin $1 \times 60 \mathrm{mg} / \mathrm{m}^{2}$, prednisone $40 \mathrm{mg} / \mathrm{m}^{2}$ for 5 days. The intensity of treatment (number of chemotherapy cycles and radiotherapy) depended on the clinical stage. Similarly, the selected patients diagnosed previously with solid tumours were treated with appropriate protocols, with or without infradiaphragmatic radiotherapy. Patients after bone marrow transplantation (BMT) received conditioning megachemotherapy composed of busulphan $3 \times 16 \mathrm{mg} / \mathrm{kg} /$ day and cyclophosphamide $4 \times 200 \mathrm{mg} / \mathrm{kg} /$ day. Between the time of the first and second hormonal measurements all the patients were in clinical remission, with no cancer recurrence, and did not receive anticancer treatment during this period. At the time of treatment, 14 girls were in Tanner stage 1-2, 9 girls in Tanner stage 3-4, and 10 in Tanner stage 5. Five of them received hormonal therapy at the time of anticancer treatment (depot medroxyprogesterone acetate intramuscularly or ethynylestradiol with desogestrel orally). At the time of the second analysis, 24 women had regular menstrual cycles, 6 had less regular cycles (between 25 and 35 days), whereas 4 presented oligomen- orrhea ( 3 after bone marrow transplantation and one after pelvic irradiation) and received hormonal replacement therapy. None of the remaining patients took oral contraceptive at the time of the measurements or after therapy.

The values of $\mathrm{AMH}$, estradiol (E2), FSH, and $\mathrm{LH}$ in the study group were compared with the results obtained from healthy 34 young women aged $17.8-31.6$ years $[\mathrm{x}$ (average $)=20.68 \mathrm{SD}=4.34$ ] with normal menstrual cycles.

\section{Hormone level measurements}

Serum concentrations of FSH (normal values: $2.8-10 \mathrm{mIU} / \mathrm{ml}$ ), LH (normal values: $1.1-11.6 \mathrm{mIU} / \mathrm{ml}$ ), and E2 (normal values: $12.5-166 \mathrm{pg} / \mathrm{ml}$ ) were performed in the same laboratory using the commercially available immunoenzymatic kits; serum AMH levels (normal values: $2.2-4 \mathrm{ng} / \mathrm{ml}$ ) were performed with the EIA AMH/MIS kit (Immunotech, Beckman Coulter Company, Marseille, France). All hormonal measurements were performed in the early follicular phase (2-4 days of menstrual cycle) and stored at $-80^{\circ} \mathrm{C}$. Only 5 patients accepted an ovarian transvaginal ultrasound examination at the first time to determine the ovarian volume and the number of small antral follicles; we decided not to present the results of these measurements.

The study was approved by the local Medical Ethics Committee. Hormone measurements were made after obtaining informed consent from the patients.

\section{Statistical analysis}

Results are expressed as mean \pm standard deviation. The normality of data distribution was assessed by the Shapiro-Wilk test. For normally distributed variables the paired and unpaired Student's $t$-test was used and otherwise Mann-Whitney U-test and Wilcoxon test for pairs. Results were considered to be statistically significant if $\mathrm{p}<0.05$. Statistical analysis was performed with the use of the SPSS statistical package.

\section{Results}

At the time of the first analysis, the mean values of AMH were lower in the high risk group (HR) $(x=2.06 \mathrm{ng} / \mathrm{ml} \pm 1.72$, min: $0.25 \mathrm{ng} / \mathrm{ml}$, max: $7.66 \mathrm{ng} / \mathrm{ml}$ ) as compared to the median risk (MR) and low risk (LR) group taken together $(4.10 \mathrm{ng} / \mathrm{ml} \pm 2.34$, min: $1.04 \mathrm{ng} / \mathrm{ml}$, max: $8.61 \mathrm{ng} / \mathrm{ml}), \mathrm{p}=0.006$, and to the control group $(3.79 \mathrm{ng} / \mathrm{ml} \pm 1.25), \mathrm{p}=0.001$. There was no difference between the LR+MR group and the control, $p=0.614$ ( $\bullet$ Fig. 1). The mean values of FSH were elevated (on the limit of statistical significance) in the $\mathrm{HR}$ group $(19.53 \mathrm{mIU} / \mathrm{ml} \pm 31.73$, min: $3.2 \mathrm{mIU} / \mathrm{ml}$, max: $61.3 \mathrm{mIU} / \mathrm{ml}$ ) as compared to the control $(5.36 \mathrm{mIU} / \mathrm{ml} \pm 1.9) \mathrm{p}=0.053$, whereas they were normal in the $\mathrm{LR}+\mathrm{MR}$ group $(6.72 \mathrm{mIU} / \mathrm{ml} \pm 2.73$, $\mathrm{min}: 2.2 \mathrm{mIU} / \mathrm{ml}$, max: $9.7 \mathrm{mIU} / \mathrm{ml}$ ), $\mathrm{p}=0.06$ ( $\odot$ Fig. 2 ).

The mean values of LH did not differ statistically between the HR (7.85 mIU/ml \pm 8.86 , $\mathrm{min}: 1.0 \mathrm{mIU} / \mathrm{ml}$, $\max : 29.1 \mathrm{mIU} / \mathrm{ml}$ ), $\mathrm{p}=0.957$, $\mathrm{LR}+\mathrm{MR}$ risk group $(4.79 \mathrm{mIU} / \mathrm{ml} \pm 4.0, \mathrm{~min}: 1 \mathrm{mIU} / \mathrm{ml}$, max: $12 \mathrm{mIU} /$ $\mathrm{ml}$ ), and control (5.26 mIU/ml \pm 4.1$), \mathrm{p}=0.728$ ( $\bullet$ Fig. 3). Similarly, we observed no differences in E2 levels between the control $(53.32 \mathrm{pg} / \mathrm{ml} \pm 41.15)$ and the HR group $(44.17 \mathrm{pg} / \mathrm{ml} \pm 38.72$, min: $5.0 \mathrm{pg} / \mathrm{ml}, \max : 130.7 \mathrm{pg} / \mathrm{ml}) \mathrm{p}=0.248$, and the $\mathrm{LR}+\mathrm{MR}$ group (38.67 pg/ml \pm 38.13 , $\mathrm{min}: 10.15 \mathrm{pg} / \mathrm{ml}$, max: $78.18 \mathrm{pg} / \mathrm{ml}$ ), $\mathrm{p}=0.096(\odot$ Fig. 4).

At the time of the second examination the mean level of $\mathrm{AMH}$ was lower in the HR group $(0.96 \mathrm{ng} / \mathrm{ml} \pm 0.81, \mathrm{~min}: 0.12 \mathrm{ng} / \mathrm{ml}$, 
max: $3.0 \mathrm{ng} / \mathrm{ml}$ ) as compared to the first analysis, the mean difference between them being $\Delta=1.10 \mathrm{ng} / \mathrm{ml} \pm 2.03, \mathrm{p}=0.03$. In the $\mathrm{LR}+\mathrm{MR}$ group, $\mathrm{AMH}$ values decreased to $2.68 \mathrm{ng} / \mathrm{ml} \pm 2.47$ (min: $0.71 \mathrm{ng} / \mathrm{ml}$, max: $7.95 \mathrm{ng} / \mathrm{ml}), \Delta=1.42 \mathrm{ng} / \mathrm{ml} \pm 2.38, \mathrm{p}=0.05$ and were lower than in the control group $(\mathrm{p}=0.027)$ ( $\bullet$ Fig. 1). FSH values increased in the HR group to $29.41 \mathrm{mIU} / \mathrm{ml} \pm 42.86$ ( $\mathrm{min}$ : $2 \mathrm{mIU} / \mathrm{ml}$, max: $78.2 \mathrm{mIU} / \mathrm{ml}$ ), the difference between the first and the second analysis being $\Delta=-8.70 \mathrm{mIU} / \mathrm{ml} \pm 28.22, \mathrm{p}=0.018$. In the $\mathrm{LR}+\mathrm{MR}$ group they did not change $(7.45 \mathrm{mIU} / \mathrm{ml} \pm 2.99$, $\min : 4.51 \mathrm{mIU} / \mathrm{ml}$, max: $13.7 \mathrm{mIU} / \mathrm{ml}), \Delta=-0.97 \mathrm{mIU} / \mathrm{ml} \pm 3.28$, $\mathrm{p}=0.325$ ( $\odot$ Fig. 2 ). The mean values of $\mathrm{LH}$ were elevated in the HR group to $15.16 \mathrm{mIU} / \mathrm{ml} \pm 13.30$ ( $\mathrm{min}: 2.58 \mathrm{mIU} / \mathrm{ml}$, max: $42.7 \mathrm{mIU} / \mathrm{ml}), \Delta=-6.49 \mathrm{mIU} / \mathrm{ml} \pm 9.47, \mathrm{p}=0.004$, as well as in the $\mathrm{LR}+\mathrm{MR}$ group $(5.65 \mathrm{mIU} / \mathrm{ml} \pm 3.23$, $\min : 1.4 \mathrm{mIU} / \mathrm{ml}$, max: $12.5 \mathrm{mIU} / \mathrm{ml}$ ), $\Delta=-1.46 \mathrm{mIU} / \mathrm{ml} \pm 2.22, \mathrm{p}=0.044$ ( $\odot$ Fig. 3 ).

E2 levels remained unchanged in the HR group $(35.59 \mathrm{pg} /$ $\mathrm{ml} \pm 20.98$, $\min : 11.06 \mathrm{pg} / \mathrm{ml}, \max : 74.1 \mathrm{pg} / \mathrm{ml}), \Delta=9.96 \mathrm{pg} /$ $\mathrm{ml} \pm 35.87, \mathrm{p}=0.435$, and in the LR+MR group $(31.84 \mathrm{pg} /$ $\mathrm{ml} \pm 13.53$, min: $22.9 \mathrm{pg} / \mathrm{ml}$, max: $52.15 \mathrm{pg} / \mathrm{ml}), \Delta=7.51 \mathrm{pg} /$ $\mathrm{ml} \pm 38.24, \mathrm{p}=0.51$ ( $\odot$ Fig. 4 ).

Abnormal (low and very low) AMH values (number and percentage) were found in the HR group ( $25 \%$ and $35 \%$, respectively) in the first examination. Very low AMH values were observed in $70 \%$ of survivors at the time of the second examination. In the $\mathrm{LR}+\mathrm{MR}$ group we found no survivors presenting very low AMH levels in the first examination; however, they appeared in the second one (38\%). Similarly, elevated FSH levels $>2$ SD were observed in $30 \%$ of HR patients at baseline and in $40 \%$ in the second examination ( $\bullet$ Table 2 ).

We separated a group of survivors diagnosed with Hodgkin lymphoma. At the time of the first analysis, we found normal values of AMH $(2.96 \mathrm{ng} / \mathrm{ml} \pm 2.05), \quad$ FSH $(6,88 \mathrm{mIU} / \mathrm{ml} \pm 3.41), \quad$ LH $(3.83 \mathrm{mIU} / \mathrm{ml} \pm 2.12)$, and $\mathrm{E} 2(47.24 \mathrm{pg} / \mathrm{ml} \pm 31.60)$, whereas at the time of the second examination we observed a difference compared to the control: AMH was lower $(1.26 \mathrm{ng} / \mathrm{ml} \pm 0.84)$, $\mathrm{p}=0.001$, FSH increased to $9.64 \mathrm{mIU} / \mathrm{ml} \pm 3.25(\mathrm{p}=0.001)$. The mean level of LH did not change statistically $(8.63 \mathrm{mIU} / \mathrm{ml} \pm 9.44)$, $\mathrm{p}=0.07$ and E2 levels were comparable $(40.08 \mathrm{pg} / \mathrm{ml} \pm 18.09)$, $\mathrm{p}=0.33$. However, differences were noted between the first and second examination: in $\Delta$ AMH values $=1.69 \mathrm{ng} / \mathrm{ml} \pm 2.32, \mathrm{p}=0.022$; in FSH values $\Delta=-3.10 \mathrm{mIU} / \mathrm{ml} \pm 3.97, \mathrm{p}=0.027$; in $\mathrm{LH}$ levels $\Delta=-4.89 \mathrm{mIU} / \mathrm{ml} \pm 10.3, \mathrm{p}=0.033$ and $\Delta$ E2 values $10.44 \mathrm{pg} /$ $\mathrm{ml} \pm 37.54, \mathrm{p}=0.40$ (॰ Fig. 1-4).

Similarly, in patients diagnosed with solid tumours classified for HR group we found lower AMH values than in LR+MR group at the time of the first examination $(0.50 \mathrm{ng} / \mathrm{ml} \pm 0.19$ vs. $4.64 \mathrm{ng} /$ $\mathrm{ml} \pm 2.46, \mathrm{p}=0.009)$, and a tendency to lower values in the second examination $(0.65 \mathrm{ng} / \mathrm{ml} \pm 0.39 \mathrm{vs} .2 .67 \mathrm{ng} / \mathrm{ml} \pm 2.12, \mathrm{p}=0.064)$. $\mathrm{LH}$ values were elevated in the HR group (compared to the LR+MR group) at the time of the second examination $(27.75 \mathrm{mIU} /$ $\mathrm{ml} \pm 21.14$ vs. $5.08 \mathrm{mIU} / \mathrm{ml} \pm 3.15, \mathrm{p}=0.036$ ). The values of FSH and E2 remained statistically unchanged ( $\odot$ Fig. 1-4). We observed no influence of age at treatment on the differences in hormone levels at the time of the first and second analyses.

\section{Discussion}

$\nabla$

Gonadal damage, and in consequence infertility or impaired fertility, pose a problem for a significant number of survivors. The risk of infertility depends on disease itself, its type, intensity and age at treatment. Although acute ovarian failure is rarely observed in childhood cancer survivors, the risk of developing premature menopause, with their various consequences such as metabolic syndrome, osteoporosis and psychosexual dysfunction, is 13-fold higher than that of siblings [10,11]. Based on the proposition made by Wallace et al., we divided our group according to the type of malignancy and treatment. This division into risk groups depends on gonadotoxicity of treatment (alkylating agents or/and radiotherapy to the pelvis, abdomen or total body

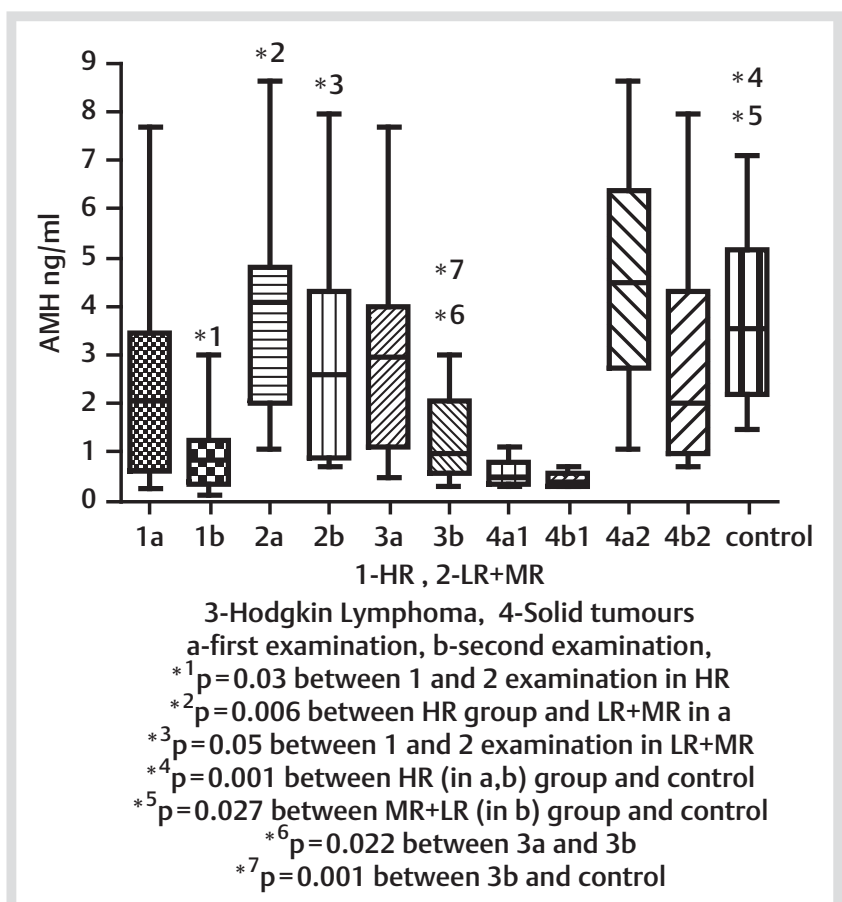

Fig. 1 Anti-Müllerian hormone levels in the study groups of cancer survivors and in the control group. AMH: Anti-Müllerian hormone; HR: High risk; MR: Medium risk; LR: Low risk.

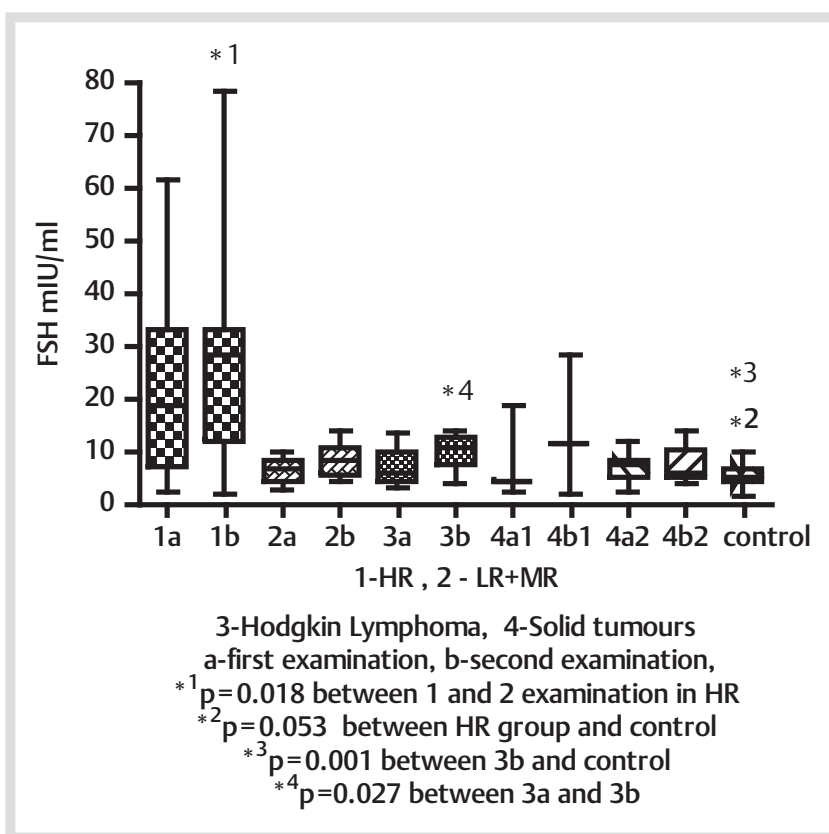

Fig. 2 FSH levels in the study groups of cancer survivors and in the control group. FSH: Follicle-stimulating hormone; HR: High risk; MR: Medium risk; LR: Low risk. 
irradiation) [5]. The results obtained were analysed from the low and median risk groups jointly due to a small number of patients classified into the median risk group (4 survivors). The levels of AMH were measured as currently the best predictor for the follicular reserve. AMH is a product of growing follicles, from the

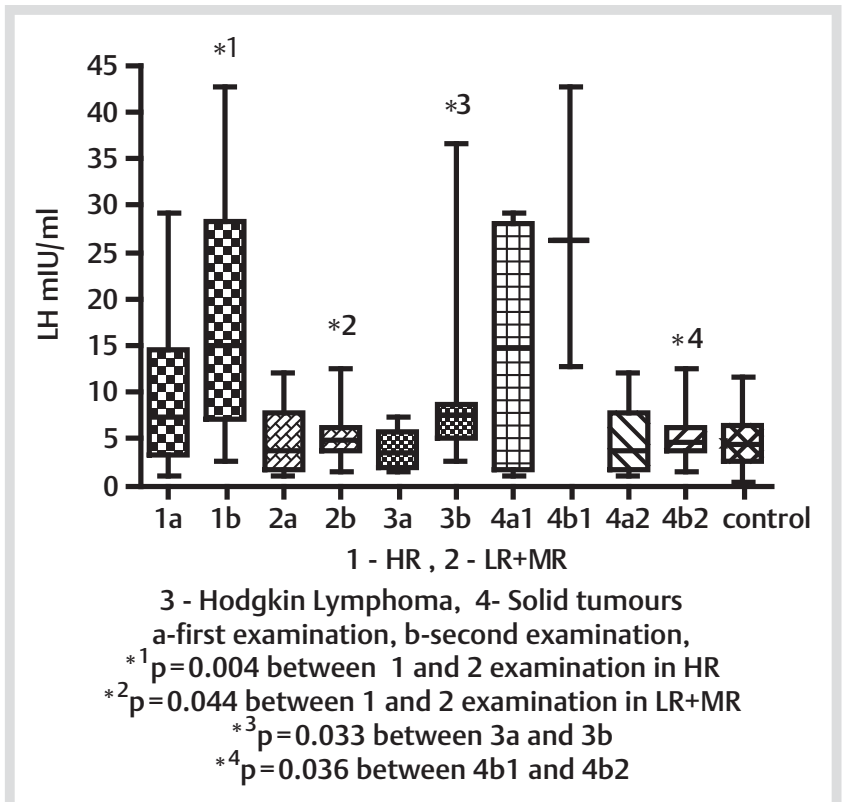

Fig. 3 LH levels in the study groups of cancer survivors and in the control group. LH: Luteinizing hormone; HR: High risk; MR: Medium risk; LR: Low risk.

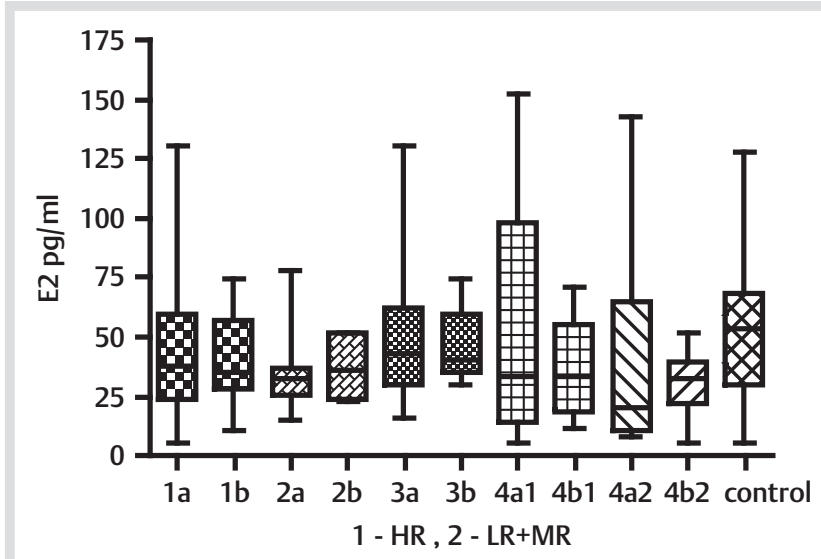

3 - Hodgkin Lymphoma, 4- Solid tumours a-first examination, b-second examination

Fig. 4 Estradiol levels in the study groups of cancer survivors and in the control group. E2: Estradiol; HR: High risk; MR: Medium risk; LR: Low risk. stage of the primary follicle to the initial formation of the antrum. In healthy women, lowered AMH level can predict the time of future menopause $[6,8]$. Similarly, in women after gonadotoxic treatment, a fall in AMH levels indicates the degree of ovarian reserve depletion, even better than ultrasound measurement $[12,13]$. In healthy women, the levels of AMH are relatively constant from mid-childhood to early adulthood (from 8 to 25 year of age) [7]. Therefore, we compared our results from the first and second examination with the same control group, in the same age range. At the time of the first examination, performed 6-11 years after treatment termination, we found normal values of all study hormones in the low + median risk group. In the high risk group, the levels of AMH were lower than in the control and in the low + median risk group, and a tendency to higher (than in the control group) FSH levels $(p=0.053)$ was observed with simultaneously normal levels of estradiol. These findings can indicate a poor ovarian reserve. The first symptom, that is, a progressive increase in FSH, appears approximately 20 years prior to menopause, whereas the overt ones (elevated FSH and diminished $\mathrm{AMH}$ ) are observed 4 years prior to menopause [14-17]. The values of LH remained within the normal range, which results from premature ovarian failure $[18,19]$. In the HR group, 13 patients were diagnosed with HL. All of them received three or four cycles of MOPP and B-DOPA protocols with or without inverted $\mathrm{Y}$ irradiation to the infradiaphragmatic areas. Franchi-Rezqui et al. have suggested that the application of 3 or more MOPP cycles is sufficient for premature ovarian failure (POF) [20]. Alkylating agents, especially procarbazine in a higher cumulative dose, are responsible for POF, whereas B-DOPA used for $\mathrm{HL}$ treatment does not exhibit a gonadotoxic effect. According to the results obtained by De Bruin et al., MOPP protocol is more toxic than irradiation to the paraaortic nodes, but the degree of toxicity rises when the field of radiation includes the ovaries [21]. Behringer et al. have described a dose-dependent cytotoxic effect of alkylating agent indicating that acute toxicity provokes reduction in the number of follicles, whereas chronic toxicity leads to their premature atresia [22]. We found no influence of age at the time of treatment; all our patients after megachemotherapy and diagnosed with HL, except one, were treated in the pubertal period. Similarly, Hamre et al. and van Beek et al. did not demonstrate the influence of age at treatment (puberty, prepuberty) on hormone levels $[18,23]$, whereas De Bruin et al. in a large cohort (518 survivors aged 14-40 years at the time of diagnosis) observed a longer time to premature menopause in women treated at a younger age [21,24]. At the time of our first analysis, the most serious hormonal disturbances were observed in patients after megachemotherapy as a conditioning before bone marrow transplantation (BMT) and in one patient subjected to pelvic irradiation $(15 \mathrm{~Gy}$ ) during childhood. Although Schuck et al. found the most serious and frequent ovarian failure in a young patient ( $<30$ years of age) after irradiation of $>15 \mathrm{~Gy}$

\begin{tabular}{|lclll|} 
Risk group & $\begin{array}{c}\text { \% of patients with } \\
\text { AMH value impair- } \\
\text { ment }(<\mathbf{2 . 2} \text { ng/ml) }\end{array}$ & $\begin{array}{l}\text { \% of patients with } \\
\text { FSH impairment } \\
(>\mathbf{1 0} \text { mlU/ml) }\end{array}$ & $\begin{array}{l}\text { \% of patients with LH } \\
\text { values impairment }\end{array}$ & $\begin{array}{l}\text { \% of patients with E2 } \\
\text { values impairment }\end{array}$ \\
\hline HR I & $6 / 20(30 \%)$ & $5 / 20(25 \%)$ & $3 / 20(15 \%)$ & $1 / 20(5 \%)$ \\
\hline MR + LR I & $7 / 13(53 \%)$ & $2 / 13(15 \%)$ & $2 / 13(15 \%)$ & $3 / 13(23 \%)$ \\
\hline HR II & $15 / 20(75 \%)$ & $8 / 20(40 \%)$ & $4 / 20(20 \%)$ & $1 / 20(5 \%)$ \\
MR + LR II & $8 / 13(61 \%)$ & $4 / 13(30 \%)$ & $2 / 13(15 \%)$ & $3 / 13(23 \%)$
\end{tabular}

HR: High risk; MR: Medium risk; LR: Low risk; FSH: Follicle-stimulating hormone; LH: Luteinizing hormone; E2: Estradiol; AMH: AntiMüllerian hormone
Table 2 Number of patients with hormone values indicating fertility impairment in the groups $\mathrm{HR}$ and $M R+L R$ at first (I) and second (II) examination. 
directed to both ovaries, Wallace et al. determined $\mathrm{LD}_{50}$ for the human oocytes to be $<2 \mathrm{~Gy}[25,26]$. Li Fong et al., in the female group of cancer survivors after total body irradiation and high dose of cyclophosphamide, observed a significant AMH decrease with increased FSH and amenorrhea [27]. Borgmann-Staudt et al. have indicated that treatment during puberty and high doses of busulphan are the principle risk factors for ovarian toxicity in women after BMT, whereas in men it is the treatment in the prepubertal period and total body irradiation (TBI) [28]. Treatment for solid tumours, with pelvis or spinal irradiation or/with alkylating agents, leads to POF [29-31].

The hormonal analyses were repeated after the next 5 years and significant changes were found in the investigated hormones. In all the HR group, the AMH levels (lower compared to the control group at the time of the first examination) diminished twice (from $\mathrm{x}=2.05 \mathrm{ng} / \mathrm{ml}$ to $0.96 \mathrm{ng} / \mathrm{ml}, \Delta=1.09 \mathrm{ng} / \mathrm{ml}$ ), FSH rose (from $\mathrm{x}=19.53 \mathrm{mIU} / \mathrm{ml}$ to $29.41 \mathrm{mIU} / \mathrm{ml}, \Delta=-8.70 \mathrm{mIU} / \mathrm{ml}$ ) and $\mathrm{LH}$ (normal at first measurement) was elevated (from $\mathrm{x}=7.85 \mathrm{mIU} /$ $\mathrm{ml}$ to $15.15 \mathrm{mIU} / \mathrm{ml}, \Delta=-6.49 \mathrm{mIU} / \mathrm{ml})$. In the $\mathrm{LR}+\mathrm{MR}$ group, the hormone levels were comparable to the first results, except for $\mathrm{LH}$ values which increased (from $\mathrm{x}=8.67 \mathrm{mIU} / \mathrm{ml}$ to $15.16 \mathrm{mIU} / \mathrm{ml}$, $\Delta=-6.49 \mathrm{mIU} / \mathrm{ml}$ ); however, the comparison of the second measurement with the control group indicated deterioration of $\mathrm{AMH}$ and FSH values. The increase noted between the first and second analysis in the number (and percentage) of survivors presenting very low AMH values and elevated FSH levels in the HR group as well as elevated AMH levels in the LR+MR group indicates progressive deterioration of ovarian function and diminished ovarian reserve not only in the HR group but also in the LR+MR group. In HL survivors, as well as in patients treated for solid tumours classified for HR group, the changes were similar to those in the total HR group.

In our opinion, it is the first prospective study presenting longtime ovarian function in young women treated previously (several years earlier) for cancer during childhood and adolescence. Our results suggest a serious loss of the primordial follicle pool and progressive ovarian failure, especially in the HR group. Brougham et al. made the prospective study in a group of female patients during and after treatment (12 months). In the low and median risk group they found a progressive AMH lowering at the time of treatment with recovery after 1 year, whereas in the HR group the recovery was not observed. They suggested the possibility of restoration of the pool of small growing follicles after less gonadotoxic therapy [24]. Morse et al. observed a group of female patients during and up to three years after cancer treatment and found the symptoms of ovarian damage at both time points, especially in patients radiated infradiaphragmatically or after BMT [32]. In our LR + MR group, the values of AMH lowered and FSH rose, thus indicating a decline in the number of oocytes, more accelerated than in healthy women. Taken together, our results show that after anticancer treatment the "fertility window" is shorter than in healthy women, particularly in the HR group.

All patients, except for those after BMT and pelvic irradiation, presented normal menstrual cycles. Similarly, Larsen et al. have shown in cancer survivors with normal values of FSH and regular menses, a diminished number of small follicles and total number of follicles, thus suggesting that ovarian age is higher than chronological age. These regular menses can lead to misconception that ovarian potential is normal [29]. According to Childhood Cancer Survivor Study, the possibility of POF refers to $8 \%$ of women, whereas in patients after more gonadotoxic treat- ment increases to $30 \%$ [3]. This suggests the necessity of counselling among female cancer survivors on diminished ovarian reserve and the risk of premature menopause, as well as on the possibilities of fertility preservation.

The analysis is limited by a small number of patients. We did not take into consideration the cumulative doses of gonadotoxic cytostatics, different models of chemotherapy or the doses and areas of irradiation. We have now collected a group of 90 young women treated previously for different cancers and we will continue this prospective study in a larger group.

In conclusion, our findings indicate that anticancer treatment during childhood and adolescence is associated with a serious, progressive risk of ovarian failure. It is necessary to inform female cancer survivors about the risk of premature menopause, especially those classified into the high risk group.

\section{Acknowledgements}

This work was supported by the Medical University of Bialystok, Poland (grant numbers: 4-79575 L/2007 and 123-79667 L/2012).

\section{Declaration of Interest}

$\nabla$

The authors declare that there is no conflict of interest that could be perceived as prejudicing the impartiality of the research reported.

\section{References}

1 Brougham MF, Wallace WH. Subfertility in children and young people treated for solid and haematological malignancies. Br J Haematol 2005; 131: 143-155

2 Bath LE, Anderson RA, Critchley HO, Kelnar CJ, Wallace WH. Hypothalamic-pituitary-ovarian dysfunction after prepubertal chemotherapy and cranial irradiation for acute leukaemia. Hum Reprod 2001; 16 : 1838-1844

3 Green DM, Sklar CA, Boice JD Jr, Mulvihill JJ, Whitton JA, Stovall M, Yasui $Y$. Ovarian Failure and reproductive outcomes after childhood cancer treatment: results from the Childhood Cancer Survivor Study. J Clin Oncol 2009; 27: 2374-2381

4 Lutchman Singh K, Davies M, Chatterjee R. Fertility in female cancer survivors: pathophysiology, preservation and the role of ovarian reserve testing. Hum Reprod Update 2005; 11: 69-89

5 Wallace WH, Anderson RA, Irvine DS. Fertility preservation for young patients with cancer: who is at risk and what can be offered? Lancet Oncol 2005; 6: 209-218

6 Anderson RA, Nelson SM, Wallace WH. Measuring anti-Müllerian hormone for the assessment of ovarian reserve: when and for whom is it indicated? Maturitas 2012; 71: 28-33

7 Hagen CP, Aksglaede L, Sorensen K, Hagen C, Main KM, Boas M, Cleemann L, Holm K, Gravholt CH, Andersson AM, Pedersen AT, Petersen $J H$, Linneberg A, Kjaergaard S, Juul A. Serum Levels of Anti-Müllerian hormone as a marker of ovarian function in 926 healthy females from birth to adulthood and in 172 Turner syndrome patients. J Clin Endocrinol Metab 2010; 95: 5003-5010

8 Broer SL, Eijkemans MJ, Scheffer GJ, van Rooij IA, de vet A, Themmen $A P$, Laven JS, de jong FH, Te Velde ER, Fauser BC, Broekmans FJ. AntiMüllerian hormone predicts menopause: a long-term follow-up study in normoovulatory women. J Clin Endocrinol Metabol 2011; 96: 2532-2539

9 Krawczuk-Rybak M, Leszczynska E, Wysocka J, Zelazowska-Rutkowska $B$. Anti-Müllerian hormone in young women after chemotherapy and infradiaphragmatic radioterapy for childhood cancer. Pediatr Endocrinol Diabetes Metab 2008; 14: 99-103

10 Chemaitilly W, Mertens AC, Mitby P, Whitton J, Stovall M, Yasui Y, Robison LL, Sklar CA. Acute ovarian failure in the childhood cancer survivor study. J Clin Endocrinol Metab 2006; 91: 1723-1728 
11 Sklar CA, Mertens AC, Mitby P, Whitton J, Stovall M, Kasper C, Mulder $J$, Green D, Nicholson HS, Yasui Y, Robison LL. Premature menopause in survivors of childhood cancer: a report from the childhood cancer survivor study. J Natl Cancer Inst 2006; 98: 890-896

12 Larsen EC, Muller J, Schmiegelow K, Rechnitzer C, Andersen AN. Reduced ovarian function in long-term survivors of radiation- and chemotherapy-treated childhood cancer. J Clin Endocrinol Metab 2003; 88: 5307-5314

13 Lie Fong S, Laven JS, Hakvoort-Cammel FG, Schipper I, Visser JA, Themmen AP, de jong FH, van den Heuvel-Eibrink MM. Assessment of ovarian reserve in adult childhood cancer survivors using anti-Müllerian hormone. Hum Reprod 2009; 24: 982-990

14 Loverro G, Guarini A, Di Naro E, Giacomantonio L, Lavopa C, Liso V. Ovarian function after cancer treatment in young women affected by Hodgkin disease (HD). Hematology 2007; 12: 141-147

15 Bath LE, Wallace WH, Shaw MP, Fitzpatrick C, Anderson RA. Depletion of ovarian reserve in young women after treatment for cancer in childhood: detection by anti-Müllerian hormone, inhibin B and ovarian ultrasound. Hum Reprod 2003; 18: 2368-2374

16 Ahmed Ebbiary NA, Lenton EA, Cooke ID. Hypothalamic-pituitary agenting: progressive increase in FSH and LH concentrations throughout the reproductive life in regularly menstruating women. Clin Endocrinol (Oxf) 1994; 41: 199-206

17 van Rooij IA, Id Tonkelaar, Broekmans FJ, Looman CW, Scheffer GJ, de Jong FH, Themmen AP, te Velde ER. Anti-müllerian hormone is a promising predictor for the occurrence of the menopausal transition. Menopause 2004; 11: 601-606

18 van Beek RD, van den Heuvel-Eibrink MM, Laven JS, de Jong FH, Themmen AP, Hakvoort-Cammel FG, van den Bos C, van den Berg H, Pieters $R$, de Muinck Keizer-Schrama SM. Anti-Müllerian hormone is a sensitive serum marker for gonadal function in women treated for Hodgkin's lymphoma during childhood. J Clin Endocrinol Metab 2007; 92: 3869-3874

19 Welt CK, Hall JE, Adams JM, Taylor AE. Relationship of estradiol and inhibin $B$ to the follicle - stimulating hormone variability in hypergonadotropic hypogonadism or premature ovarian failure. J Clin Endocrinol Metab 2005; 90: 826-830

20 Franchi-Rezgui P, Rousselot P, Espié M, Brière J, Pierre Marolleau J, Gisselbrecht $C$, Brice $P$. Fertility in young women after chemotherapy with alkylating agents for Hodgkin and non-Hodgkin lymphomas. Hematol J 2003; 4: 116-120

21 De Bruin ML, Huisbrink J, Hauptmann M, Kuenen MA, Ouwens GM, van't Veer MB, Aleman BM, van Leeuwen FE. Treatment-related risk factors for premature menopause following Hodgkin lymphoma. Blood 2008; 111: $101-108$
22 Behringer K, Breuer K, Reineke T, May M, Nogova L, Klimm B, Schmitz $T$, Wildt L, Diehl V, Engert A.German Hodgkin's Lymphoma Study Group. Secondary amenorrhea after Hodgkin's lymphoma is influenced by age at treatment, stage of disease, chemotherapy regimen, and the use of oral contraceptives during therapy: a report from the German Hodgkin's Lymphoma Study Group. J Clin Oncol 2005; 23: 7555-7564

23 Hamre H, Kiserud CE, Ruud E, Thorsby PM, Fossa SD. Gonadal function and parenthood 20 years after treatment for childhood lymphoma: A Cross-Sectional Study. Pediatr Blood Cancer 2012; 59: 271-277

24 Brougham MF, Crofton PM, Johnson EJ, Evans N, Anderson RA, Wallace WH. Anti-Müllerian Hormone Is a Marker of Gonadotoxicity in Preand Postpubertal Girls Treated for Cancer: A Prospective Study. J Clin Endocrinol Metab 2012; 97: 2059-2067

25 Schuck A, Hamelmann V, Brämswig JH, Könemann S, Rübe C, Hesselmann S, Riesenbeck D, Horst E, Bölling T, Paulussen M, Jürgens H, Willich $N$. Ovarian function following pelvic irradiation in prepubertal and pubertal girls and young adult women. Strahlenther Onkol 2005; 181: 534-539

26 Wallace $W H$, Thomson $A B$, Kelsey TW. The radiosensitivity of the human oocyte. Hum Reprod 2003; 18: 117-121

27 Lie Fong S, Lugtenburg PJ, Schipper I, Themmen AP, de Jong FH, Sonneveld $P$, Laven JS. Anti-müllerian hormone as a marker of ovarian function in women after chemotherapy and radiotherapy for haematological malignancies. Hum Reprod 2008; 23: 674-678

28 Borgmann-Staudt A, Rendtorff R, Reinmuth S, Hohmann C, Keil T, Schuster FR, Holter W, Ehlert K, Keslova P, Lawitschka A, Jarisch A, Strauss $G$. Fertility after allogeneic haematopoietic stem cell transplantation in childhood and adolescence. Bone Marrow Transplant 2012; 47: 271-276

29 Larsen EC, Muller J, Rechnitzer C, Schmiegelow K, Andersen AN. Diminished ovarian reserve in female childhood cancer survivors with regular menstrual cycles and basal FSH<10 IU/l. Hum Reprod 2003; 18: 417-422

30 Lantinga GM, Simons AH, Kamps WA, Postma A. Imminent ovarian failure in childhood cancer survivors. Eur J Cancer 2006; 42: 1415-1420

31 Balcerek M, Reinmuth S, Hohmann C, Keil T, Borgmann-Staudt A. Suspected Infertility After Treatment for Leukemia and Solid Tumors in Childhood and Adolescence. Dtsch Arztebl Int 2012; 109: 126-131

32 Mörse H, Elfving M, Lindgren A, Wölner-Hanssen P, Andersen CY, Øra I. Acute onset of ovarian dysfunction in young females after start of cancer treatment. Pediatr Blood Cancer 2013; 60: 676-681 